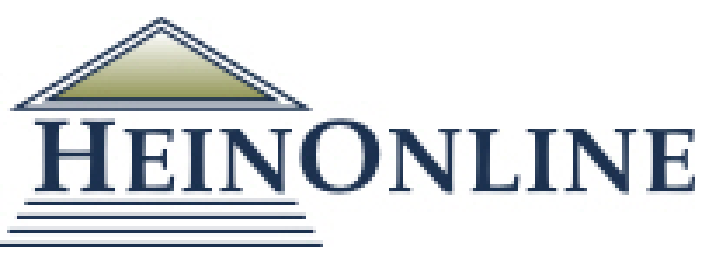

Content downloaded/printed from

HeinOnline

Fri Sep 27 20:49:39 2019

Citations:

Bluebook 20th ed.

Ebenezer Durojaye, Turning Paper Promises to Reality: National Human Rights Institutions and Adolescents' Sexual and Reproductive Rights in Africa, 26 Neth. Q. Hum. Rts. 547 (2008).

ALWD 6th ed.

Ebenezer Durojaye, Turning Paper Promises to Reality: National Human Rights Institutions and Adolescents' Sexual and Reproductive Rights in Africa, 26 Neth. Q. Hum. Rts. 547 (2008).

APA 6th ed.

Durojaye, E. (2008). Turning paper promises to reality: National human rights institutions and adolescents' sexual and reproductive rights in africa. Netherlands Quarterly of Human Rights, 26(4), 547-578.

Chicago 7th ed.

Ebenezer Durojaye, "Turning Paper Promises to Reality: National Human Rights Institutions and Adolescents' Sexual and Reproductive Rights in Africa," Netherlands Quarterly of Human Rights 26, no. 4 (2008): 547-578

McGill Guide 9th ed.

Ebenezer Durojaye, "Turning Paper Promises to Reality: National Human Rights Institutions and Adolescents' Sexual and Reproductive Rights in Africa" [2008] 26:4 Nethl QHR 547.

MLA 8th ed.

Durojaye, Ebenezer. "Turning Paper Promises to Reality: National Human Rights Institutions and Adolescents' Sexual and Reproductive Rights in Africa." Netherlands Quarterly of Human Rights, vol. 26, no. 4, 2008, p. 547-578. HeinOnline.

OSCOLA 4th ed.

Ebenezer Durojaye, 'Turning Paper Promises to Reality: National Human Rights Institutions and Adolescents' Sexual and Reproductive Rights in Africa' (2008) 26 Neth Q Hum Rts 547

-- Your use of this HeinOnline PDF indicates your acceptance of HeinOnline's Terms and Conditions of the license agreement available at https://heinonline.org/HOL/License

-- The search text of this PDF is generated from uncorrected OCR text.

-- To obtain permission to use this article beyond the scope of your license, please use: Copyright Information

Use QR Code reader to send PDF to your smartphone or tablet device 


\title{
TURNING PAPER PROMISES TO REALITY: NATIONAL HUMAN RIGHTS INSTITUTIONS AND ADOLESCENTS' SEXUAL AND REPRODUCTIVE RIGHTS IN AFRICA
}

\author{
EBENEZER DURoJAYE*
}

\section{Abstract}

This article examines the history of national human rights institutions (NHRIs) in general including their establishment in Africa. Using examples from three countries Malawi, Nigeria and South Africa - it critically analyses the promotional and protective mandates of these institutions in Africa and then argues that their experience over the years in promoting human rights in their domains can similarly be useful in advancing adolescents' sexual and reproductive rights. In doing this, NHRIs may face some challenges including poor funding, undue interference from the executive, shortage of personnel and so on. Therefore some of these challenges are discussed and subsequently some suggestions for the way forward.

\section{INTRODUCTION}

Human rights of citizens enshrined in international, regional and national documents often accord to human beings certain fundamental rights such as rights to life, liberty, dignity, non-discrimination, health and so on, which are necessary for a life worthy of living. However, these rights, as enshrined in the various documents, will amount to mere rhetoric if there are no means of holding them. This is particularly the case with regard to sexual and reproductive rights as aspects of human rights, as these rights are often given little attention in Africa. Thus, the roles of national human rights institutions (NHRIs) in holding governments accountable for the realisation of these

LLD Candidate and researcher Department of Constitutional Law and Philosophy of Law, Faculty of Law, University of the Free State, Bloemfontein, South Africa. The author remains grateful to Professor Charles Ngwena of the University of the Free State and Professor Akin Oyebode of the University of Lagos for their usual encouragement and inspiration. Thanks equally go to Thapi Matsaneng and Susan Kreston for her comments on the earlier draft of the article. All internet-sites were last accessed on 1 November 2008. 
rights become imperative. NHRIs, through proper monitoring, can raise the profiles of sexual and reproductive rights, particularly with regard to adolescents within Africa. They can similarly secure and advance adolescents' sexual and reproductive rights through effective execution of their promotional and protective mandates.

Indeed, Article 4 of the Convention on the Rights of the Child (CRC) $)^{1}$ - one of the most ratified treaties in the world - enjoins States parties to the Convention to take all necessary steps including legislative, judicial, budgetary and administrative to ensure full realisation of the rights guaranteed in the Convention. Certainly, one of the ways of doing this is to ensure that NHRIs play active roles in promoting and protecting adolescents' rights in the region. Experience across Africa has shown that more and more human rights institutions are becoming active and relevant in monitoring human rights within their domains. However, these encouraging developments have not been applied to the situation of adolescents within the region, especially as regards promoting and protecting their sexual and reproductive health and rights. ${ }^{2}$

Today, in many African countries, adolescents continue to bear the greatest burden of sexual and reproductive ill health or problems. Of the estimated 330 million new cases of curable sexually transmitted infections (STIs) - excluding HIV/AIDS - each year, at least one-third of them occur in young people under the age of 25 years many of whom live in developing countries. ${ }^{3}$ Untreated STIs lead to grave consequences such as infertility and easily pave the way for HIV infection. More than half of people living with HIV in the world are young people between the ages of $15-24 .^{4}$ Of this figure, three-quarters of them are females living in sub-Saharan Africa. ${ }^{5}$ The prevalence of HIV infection among young women in this region is four times more than that of young men. Every year, throughout the world, an estimated 210 million women - majority of whom are young women - become pregnant and one in five of these pregnancies results in abortion. ${ }^{6}$ Of about 46 million abortions performed annually, majority of which are in Africa, Latin America, Caribbean and Asia, 19 million of them are estimated to be unsafe. ${ }^{\text {? }}$

1 Convention on the Rights of the Child, UN Doc. A/44/49, adopted in 1989, entered into force 2 September 1990.

2 Adolescents are often described as people in the age group of 10-19 years while young persons are within the ages of 15 to 24 years. UNDP, UNFPA, WHO and World Bank Special Programme of Research, Development and Research Training in Human Reproduction, Progress in Reproductive Health Research, WHO, Geneva, 2002, p. 1.

WHO, The Second Decade: Improving Adolescent Health and Development, WHO/FRH/ADH/98.18, Adolescent Health and Development Programme, WHO, Geneva, 1998, p. 6. UNAIDS, AIDS Epidemic Report. UNAIDS, Geneva, 2006, p. 11.

Idem.

The Alan Guttmacher Institute (AGI), Sharing Responsibility: Women, Society and Abortion Worldwide, AGI, New York, 1999, chart 1.1.

7 Ahman, E. and Shah, I., 'Unsafe abortion: Worldwide estimates for 2000', Reproductive Health Matters, Vol. 19, No. 10, 2002, pp. 13-17. 
The greatest numbers of unintended pregnancies in the world occur in developing countries including Africa. These often lead to abortion - legal or illegal - thus putting the lives of female adolescents in danger. In some cases where the female adolescent carries the pregnancy to term death resulting from pregnancy complications likely occur. It is believed that women aged 15-19 are four times more likely to die from complications of pregnancy than women aged $20-24$ years. ${ }^{8}$ Yet, use of contraceptives among adolescents especially in Africa is very poor. Many adolescents in Africa either lack information on contraception or are denied access to contraception as a result of negative practices on the part of health care providers, cultural practices or unfavourable policies on the part of governments. Finally, each year, close to three million girls and young women in Africa are at risks of undergoing female genital mutilation/cutting (FGM/C). ${ }^{9}$

Against this backdrop, it has become imperative for NHRIs in the region to be more alive to their responsibilities in advancing adolescents' sexual and reproductive health in Africa. In this article, the history of national human rights institutions in general, including their establishment, in Africa is thus examined. By using examples from three countries - Malawi, Nigeria and South Africa - the promotional and protective mandates of these institutions in Africa is critically analysed and it is then argued that their experience over the years in promoting human rights in their domains can similarly be useful in advancing adolescents' sexual and reproductive rights. However, it is realised that in doing this, NHRIs may face some challenges including poor funding, undue interference from the executive, shortage of personnel and so $o$. Therefore, some of these challenges will be discussed and some suggestions for the way forward suggested.

\section{HISTORICAL DEVELOPMENT OF NATIONAL HUMAN RIGHTS INSTITUTIONS}

The formation of the United Nations (UN) in 1945 as a result of the horrendous and grotesque abuse of humanity during the Second World War can be said to be the first catalyst for the setting up of NHRIs. The UN, which has the mandate of promoting and protecting human rights globally, acts as the umbrella body for the advancement of human rights in the world. In 1946, the foundation for the setting up of national human rights institutions was laid at the second session of the United

8 See Glassier, A. et al., 'Sexual and Reproductive Health: A matter of Life and Death', The Lancet, Vol. 368, No. 4, 2006, pp. 1595-607. See also, Rivers, R. et al., 'Contraception for Adolescents: Social, Clinical and Service Delivery Considerations, International Journal of Gynecology and Obstetrics, Vol. 75, No. 2, 2001, pp. 149-163.

9 WHO, 'Female Genital Mutilation: Key Facts', available at: www.who.int/mediacentre/factsheets/ fs $241 /$ en/. 
Nations Economic and Social Council (ECOSOC).$^{10}$ At this meeting, it was agreed that it was desirable for member States to consider establishing local bodies in form of 'information groups or local human rights committees' that will serve as a conduit for collaborations with the United Nations Human Rights Commission. ${ }^{11}$

The idea of setting up NHRIs was broached again in 1960, this time around with improvements in the responsibilities of these institutions, beyond being just agencies for information. It was suggested that these institutions should play active roles in participation and monitoring of human rights related issues. ${ }^{12}$ This situation continued for a while and with the adoption of human rights instruments in the 1960s and 1970s the call for these institutions grew stronger. It was believed that NHRIs could play pivotal roles in local implementation of the human rights instruments that were being adopted at that time..$^{13}$ For a clearer and better understanding of the roles of these institutions, a seminar on National and Local Institutions for the Promotion and Protection of Human Rights was convened in Geneva in September 1978. At this seminar, the first set of guidelines with regard to human rights institutions was adopted, including the division of these institutions into two categories. ${ }^{14}$ Firstly, they may be concerned with the general promotion of human rights, and secondly they may have to do with reviewing national policies (legislative, judicial and administrative steps and decisions and then making recommendations to the State). ${ }^{15}$

In addition, it was suggested that the composition of NHRIs should reflect a cross section of the society so as to ensure popular participation. Similarly, these institutions should be easily accessible to diverse members of the public, function on a regular basis and in certain situations receive the assistance of local or national advisory organs. ${ }^{16}$ These guidelines received the blessing of the United Nations Human Rights Commission and the General Assembly ${ }^{17}$ which requested States to comment on the guidelines and to similarly notify the Secretary General with regard to their own experiences setting up similar institutions within their countries.

The issue of NHRIs was again raised by the UN General Assembly in 1979 when it urged States to create an enabling environment for the setting up of NHRIs, bearing in mind the guidelines agreed upon a year earlier and ensuring that the independence and integrity of these institutions are guaranteed in accordance with local laws. ${ }^{18}$ The

10 See Lindsnaes, B. and Lindholt, L., 'National Human Rights Institutions: Standard Settings and Achievement', in: Lindsnaes, B. et al. (eds), National Human Rights Institutions Articles and Working Papers, Danish Centre for Human Rights, Copenhagen, Denmark, 2000, pp. 1-48.

11 See ECOSOC Resolution 2/9, 21 June 1946.

$12 \quad$ ECOSOC Resolution 772 B (XXX), 25 July 1960.

13 See Lindsnaes and Lindholt, loc.cit (note 10), p. 5.

14 St/HR/SER.A/2, chapter V, 18-29 September 1978.

15 Lindsnaes and Lindholt, loc.cit. (note 10), p. 6.

$16 \quad$ Ibidem, p. 5.

17 UN Doc. A/RES/33/46, 14 December 1978.

18 UN Doc. A/RES/34/49, 23 November 1979. 
General Assembly further emphasised the constructive roles that non-governmental organisations (NGOs) could play in the setting up of such national institutions.

In discussing the chequered history of NHRIs, it is worthy to mention the UN General Assembly Resolution of 1981 which proposes an essential formulation for national human rights institutions. The Resolution also states that 'all human rights and fundamental freedoms are indivisible and interdependent, and that equal attention and urgent consideration should be given to the implementation, promotion and protection of both civil and political, and economic, social and cultural rights' ${ }^{19}$ From this resolution it would seem that NHRIs were not to monitor civil and political rights alone, but also social and economic rights. ${ }^{20}$ This is no doubt a welcome development as it is in line with the interrelatedness and indivisibility of all human rights as affirmed at the Vienna Programme of Action. ${ }^{21}$ Additionally, the first and second reports of the Secretary General between 1981 and 1983 accorded two major functions to NHRIs: protection and promotion of human rights. ${ }^{22}$ While the former relates to activities such as hearing of complaints, seeking resolutions of cases, bringing cases before the court of law among others, the latter relates to issues such as participation in legislative process, dissemination of information and public awareness campaigns among others.

Perhaps what could be regarded as a watershed in the historical development of NHRIs was the Paris Conference on the role of National Human Right Institutions in the Promotion and Protection of Human rights which took place between 7 and 9 October 1991. At the end of this meeting, a set of guidelines and principles to regulate the activities of NHRIs emerged which is today referred to as the Paris Principles. ${ }^{23}$ The emphasis of these principles is on three main areas: (i) the responsibilities and competency of national institutions; (ii) the composition of national institutions; and (iii) the methods of operation of national institutions. Also, a particular section relating to the quasi-judicial nature of such institutions to hear, transmit and settle individual complaints was added.

Some of the essential requirements for setting up NHRIs contained in the Paris Principles include, independence, competence, pluralism of membership, a broadbased mandate set up in a constitution or a legislative act and adequacy of resources for its running. It must be noted, however, that aside from these conditions laid down in the Paris Principles for the establishment of NHRIs, the success of NHRIs will also depend on a supportive environment - existence of political will and an independent

\footnotetext{
19 See Resolution A/RES/36/134, 14 December 1981.

20 Lindsnaes and Lindholt, loc.cit. (note 10), p. 7.

21 Vienna Programme of Action, UN Doc. A/CONF 157/24, Part 1, chapter III.

22 UN Docs A/36/440, 9 October 1981; and A/38/416, 24 October 1983.

23 Human Rights Commission Resolution 1992/54, 3 March 1992 (Paris Principles).
} 
and effective judiciary. ${ }^{24}$ Even though today, the Paris Principles have almost been universally embraced, they have been criticised for imagining an ideal NHRI, a conception which may seem too limited and not necessarily reflective of the peculiar situation of a country. ${ }^{25}$ Since the Paris Conference a number of events have taken place that have had a great impact on the development of NHRIs. For instance, at the International Human Rights Conference in Vienna the importance of human rights institutions in the protection and promotion of human rights, including their role at remedying human rights violations, dissemination of information and education in human rights was reaffirmed. ${ }^{26}$

About three years after the Vienna Declaration, between 5 and 7 February 1996, another meeting known as the First African Conference of National Institutions for the Promotion and Protection of Human Rights was convened in Yaoundé, Cameroun under the auspices of the United Nations Commission on Human Rights (UNCHR) and Cameroun National Human Rights Commission. This meeting led the Yaoundé Declaration which emphasises the roles NHRIs must play regarding their responsibilities both to government and towards the promotion of human rights and provision of remedy for such violations. Prior to both the Paris Principles and the Vienna Conference, only a few human rights institutions existed in the world. ${ }^{27}$ However, things began to change as from the 1990s, as more and more human rights institutions emerged virtually in every region of the world including Africa. ${ }^{28}$

The African Charter on Human and Peoples' Rights (African Charter) ${ }^{29}$ established the African Commission on Human and Peoples' Rights, ${ }^{30}$ which became the pace-setter in the setting up of NHRIs in Africa. The combined reading of Articles 26 and $45(1)(c)$ of the African Charter gives support to the establishment of NHRIs in the region. ${ }^{31}$ Today, NHRIs take different shapes and forms. Most of them can be

24 United Nations (UN), Economic, Social and Cultural Rights: A Handbook for National Human Rights Institutions, UN, New York and Geneva; 2005, p. 32.

25 Okafor, O. and Agbakwa, S., 'On Legalism, Popular Agency and "Voices of Suffering". The Nigerian Human Rights Commission in Context', Human Rights Quarterly, Vol. 24, No. 3, 2002, pp. 662720 .

26 See Vienna Programme of Action, supra note 21, para. 36.

27 See Lindsnaes and Lindholt, loc.cit. (note 10), p. 13. These include those in France (1947), New Zealand (1978), Canada (1978), Australia (1981, reestablished in 1986), the Philippines (1987) and Denmark (1987).

28 Ibidem, Notable ones to spring up in Africa during this time include Cameroon (1991), Chad (1994), Ghana (1993), Nigeria (1996), Senegal (1997), South Africa (1995), Uganda (1996) and Zambia (1997).

29 African Charter on Human and Peoples' Rights, OAU Doc. CAB/LEG/67/3/Rev.5, adopted by the Organization of African Unity, 27 June 1981, entered into force 21 October 1986.

30 Though the Commission was established under Article 30 of the African Charter it formally came into being in 1987.

31 Article 26 of the African Charter enjoins States to ensure the establishment and improvement of national institutions entrusted with the promotion and protection of human rights Article $45(1)(c)$ on the other hand provides that the African Commission, as part of its functions, shall cooperate 
categorised in terms of their mandates, organisational composition or the political or legal traditions under which they operate. ${ }^{32}$ Furthermore, a distinction can be made between single member institutions and multi member institutions, those that deal with individual complaints and those that work on virtually all human rights including socio-economic rights. ${ }^{33}$

\section{PROMOTIONAL AND PROTECTIVE MANDATES OF NHRIs IN AFRICA}

As earlier mentioned and in line with the Paris Principles, the major important mandates of NHRIs (though not the only mandates) include the promotion and protection of human rights within their jurisdictions. Most of the NHRIs in Africa, at least carry out these mandates. It must be noted, however, that very few of these institutions focus on the violations of socio-economic rights within their countries. This section of the article will examine the ways NHRIs in Africa have over the years executed these important mandates. The focus will be on the right to health, in particular sexual and reproductive rights. The discussion here does not seek to cover every part of the region; however, examples will be drawn from the experiences of NHRIs in three countries (Malawi, Nigeria and South Africa) in the region.

The choice of these countries is informed by the diversity in their socio-economic development including their legal systems. Malawi is regarded as a least developed country, faced with challenges in its health sector and with a constitution that does not explicitly recognise the right to health. Nigeria is a developing country with a constitution which also does not recognise the right to health and is faced with weak infrastructure in virtually every facet of human endeavour including the health sector. Also, the country adopts a tripartite legal system (civil law, customary law and sharia law) and is second to South Africa in terms of the number of people living with HIV in Africa. Whereas, South Africa, with a very progressive constitution explicitly recognising the right to health, is an exception to other African countries. Though it is regarded as a developing country, its level of economic and technological development is much advanced in comparison to any other country in the region. Yet, the challenges facing adolescents as regards their sexual and reproductive health needs in these countries are almost similar.

with other African and international institutions concerned with the promotion and protection of human and peoples' rights.

32 International Council of Human Rights Policy, Assessing the effectiveness of National Human Rights Institutions, International Council of Human Rights Policy, Geneva, 2005, p. 5.

33 Idem. 


\subsection{PROMOTIONAL MANDATE}

This mandate includes activities such as dissemination of information, creation of awareness, embarking on research and documentation on human rights. Other important activities under this mandate include promoting ratification of international treaties, reviewing of national legislation in compliance with international law, reporting or making recommendations to government or parliaments on legal changes or policy issues and cooperating with the UN and regional bodies and also assisting governments in drafting of State reports to appropriate treaty monitoring bodies. It has been suggested that this mandate of NHRIs is one of their most crucial roles in preventing the abuse of human rights. ${ }^{34}$

Indeed, most of the African NHRIs have been very active with regard to this mandate. For instance, the Malawi Human Rights Commission (MHRC) was created under chapter XI of the 1994 Constitution ${ }^{35}$ and the Human Rights Commission Act of 1998 (the Act). ${ }^{36}$ Its broad mandates are clearly spelt out under section 129 of the Constitution and section 12 of the Act and they include promotion and protection of both civil and political rights and social and economic rights. These mandates cover all human rights issues guaranteed under the Malawian Constitution and other international human rights instruments to which Malawi is a signatory. As part of its promotional activities the Commission has been involved in the formulation and adoption of a policy on sexual harassment, review of laws on marriage and divorce in Malawi, liaising with civil society groups in advancing human rights and embarking on advocacy regarding wills and inheritance and prisoners' rights in the country. ${ }^{37}$ In addition, the MHRC has started research documenting cultural practices that negatively impact on women's human rights in the country. Furthermore, the MHRC has carried out series of training programmes on various aspects of human rights such as right to health, water and good sanitation, women's rights and so on. It is noteworthy that the MHRC has a Child Rights Unit to specifically monitor human rights issues relating to children.

The MHRC's report on cultural practices that affect women's enjoyment of their rights documented various cultural practices inimical to the health of women and children such as polygamy, female genital mutilation/cutting, preference of a boy as first born, issues related to marriage and funeral rites practices such as forcing women to sleep in the funeral vigil room..$^{38}$ Other cultural practices documented include child

Okafor and Agbakwa, loc.cit. (note 25), p. 687.

The Constitution of the Republic of Malawi Act 20 of 1994.

Act 27 of 1998.

See Malawi Human Rights Commission (MHRC), Annual Report of the Human Rights Commission, MHRC, Lilongwe, 2004, pp. 7-21.

38 Malawi Human Rights Commission (MHRC), Cultural Practices and their Impact on their Enjoyment of Human Rights, particularly the Rights of Women and Children in Malawi, MHRC, Lilongwe, 2006, pp. 17-41. 
and forced marriages, birth and death cleansing and incidence of child neglect. ${ }^{39}$ The report also found that maternal complications such as long labour and fistula, often a consequence of prolonged labour - due to child marriage - were rife among young mothers. It was noted by the Commission that these practices violate women's and children's rights under Malawi's law and international and regional human rights law ratified by Malawi. For instance, the Commission observed that most of these cultural practices are contrary to the Convention on the Elimination of All forms of Discrimination against Women (CEDAW) ${ }^{40}$ and the Convention on the Right of the Child ${ }^{41}$ which have been ratified by Malawi.

Therefore, the Commission made a number of recommendations including legislative transformation in order to make Malawi'slaws compatible with its obligations under international law. The Commission's report similarly captured the reporting obligations of Malawi under ratified human rights treaties. It poignantly exposed Malawi's poor performance in this respect. Out of the six ratified international human rights treaties, the country has only submitted reports to the CEDAW Committee and the Committee on the CRC. ${ }^{42}$

While it is commendable that the MHRC gives attention to the sexual and reproductive rights of adolescents in its report, the Commission fails to capture some important violations of adolescents' rights particularly regarding access to contraceptive use, high incidence of backstreet abortion causing loss of lives among young women and sexual violence. Malawi has a restrictive law on abortion which has in turn forced young people to seek unsafe abortion. One report found that adolescent women represent close to one-third of patients suffering from complications resulting from unsafe abortion in countries as Malawi, Uganda and Zambia. ${ }^{43}$ It is estimated that about 35 per cent of women in Malawi experience sexual assault in their lifetime most of whom are young persons. ${ }^{44}$ This situation has been aggravated by the myth in most part of Southern Africa that sexual intercourse with a virgin may likely lead to cure of HIV/AIDS. ${ }^{45}$ Indeed, the number of reported cases of sexual abuse of children and defilement of underage girls has continued to rise in leaps and bounds in the

39 Idem.

40 Convention on the Elimination of All Forms of Discrimination Against Women, UNGA Res. 54/180, UN GAOR, 34th Session, Supp No. 46, UN Doc. A/34/46, adopted 18 December 1979, entered into force 3 September 1981.

41 Supra note 1.

42 See Malawi Human Rights Commission, Annual Report, op.cit. (note 37), p. 5.

43 See 'Children, Youth and Unsafe abortion', available at: www.reproductiverights.org/pdf/pub_fac_ adoles_unsafeab.pdf.

44 See Pelser, E. et al., Intimate sexual violence: Results from a national gender-based violence study in Malawi, Institute for Security Studies, Pretoria, 2005, p. 17.

45 South African Law Commission, Fifth Interim Report on Aspects of the Law Relating to AIDS: The Need for a Statutory Offence aimed at HIV-related Harmful Behaviour, South African Law Commission, Pretoria, 2001, pp. 8-19. 
country. ${ }^{46}$ It is estimated that about 14 percent of the population, that is, about one million people, are living with HIV in Malawi. ${ }^{47}$ The epidemic is more intense among young women between the ages of 15-29 than their male counterparts. ${ }^{48}$

Furthermore, it has been shown that about nine percent of young women are infected compared to just two per cent of their male counterpart. In the rural areas, the prevalence is about 13 percent for young women and one percent for young men. Moreover, a study has revealed poor knowledge of the epidemic among young women in the rural areas. ${ }^{49}$ Indeed, the Committee on the CRC in one of its Concluding Observations to Malawi has expressed grave concern over the negative 'impact of the HIV/AIDS pandemic, mounting economic challenges and other socioeconomic difficulties, as well as traditional practices and witchcraft', that continue to threaten the right to life, survival and development of children in the country. ${ }^{50}$ The Committee further points out to the Malawian Government the need to address sexual and reproductive needs of adolescents in the country and to ensure their full participation in any programme designed to meet such needs. ${ }^{51}$ This obviously calls for a drastic step to be taken by the Malawian Government in line with its obligations under international and regional human rights law. It similarly, places an obligation on the MHRC to ensure that these issues are given adequate attention by the Malawian Government.

The Nigerian Human Rights Commission (NHRC) was established in $1995 .{ }^{52}$ It is empowered to deal with human rights issues under the Nigerian Constitution, African Charter, United Nations Charter and the Universal Declaration on Human Rights and other international human rights treaties that Nigeria has signed. Its major functions, among others, include investigating violations of human rights, assisting victims of human rights, undertaking studies in relation to human rights, publishing reports on human rights organising training and creating awareness on human rights in the country. The Commission has about 16 thematic areas of interest which include both civil and political rights and social and economic rights issues such as women, children, police and prison, judiciary, education, environment, food and shelter and so on. Interestingly, for each of these thematic areas of interest, a Special Rapporteur has been appointed.

This approach is quite unique and innovative as it is capable of assisting the NHRC in realising its objectives of promoting and protecting human rights in the

46 state.gov/g/drl/rls/hrrpt/2006/78744.htm.

47

48

49

50

51

52

UNAIDS, op.cit. (note 4), p. 16.

Idem.

Idem. Add.174, 2 April 2002.

Idem.

See Committee on the CRC, Concluding Observations and Comments: Malawi, UN Doc. CRC/C/15/

National Human Rights Commission Decree (Act) 1995. 
country. It seems to coincide with the recommendation of the Committee on the CRC in its General Comment No. 2. ${ }^{53}$ The Commission appears to have borrowed a leaf from the United Nations treaty bodies and the African Commission on Human and Peoples' Rights both of which employ the use of Special Rapporteurs in some of their activities. But, as discussed below, the appointment of these Rapporteurs is one thing, their effectiveness another. Also, the fact, that the mandate of the Commission similarly covers social and economic rights, is even more commendable taking into cognizance the non-justiciability of these rights under the Nigerian Constitution. ${ }^{54}$ This seems to be in line with recent developments under international law. ${ }^{55}$ The UN has urged NHRIs to adopt a comprehensive and holistic approach to the promotion and protection of all human rights including civil and political rights and social and economic rights. ${ }^{56}$

Part of the NHRC's promotional activities have included educational programmes on human rights in schools, quiz competitions on human rights, human rights training for rapporteurs and others as well as media advocacy ${ }^{57}$ In its $2005-2006$ State of Human Rights Report in Nigeria, which may be described as the first major report of the NHRC on human rights in the country, the Commission documented various human rights violations relating to women, children and young persons, health, food and shelter, and so on.

In its report on women, the NHRC noted that, despite the existence of Nigerian laws and international and regional human rights instruments relating to women's rights, which the country has ratified, discrimination against women is still rife in the country and women are treated 'as mere objects and chattels'. 58 Violations of women's rights such as sexual and domestic violence including rape as well as denial of property rights are rampant in the country. The NHRC particularly called for laws and policies tackling the endemic issue of violence against women.

53 Committee on the Rights of the Child, General Comment No. 2, The role of independent national human rights institutions in the promotion and protection of the rights of the child, UN Doc. CRC/ GC/2002/2, 15 November 2002. The Committee urges NHRIs to specifically appoint special Commissioners to monitor children's rights in the discharge of their mandates.

These rights are contained under chapter 2 of the Constitution known as Directive Principles of Government Policy which are declared to be unenforceable under section 6(6) of the same Constitution.

55 See, for instance, the Committee on Economic Social and Cultural Rights, General Comment No. 10, The Role of National Human Rights Institutions in the Protection of Economic, Social and Cultural Rights, UN Doc. E/1999/22, 14 December 1998, at para. 3 18, where the Committee enjoins NHRIs to give attention to the promotion and protection of social and economic rights within their domains.

56 United Nations (UN), op.cit. (note 23), p. 35.

57 See National Human Rights Commission, Nigeria (NHRC), Annual Report, NHRC, Abuja, 2005, pp. 17-20.

58 National Human Rights Commission, Nigeria (NHRC), State of Human Rights Reports in Nigeria 2005-2006, NHRC, Abuja, 2006, p. 72. 
With regard to children and young persons, the NHRC recommended that states that are yet to pass the Child's Rights $\mathrm{Act}^{59}$ in the country should do so immediately and those that have passed the Act into law should commence full implementation of it in their states. Surprisingly, this report did not capture issues such as sexual abuse of children, denial of access to contraception, high HIV/AIDS prevalence, deaths related to unsafe abortion and incidence of child marriage and female genital mutilation/ cutting that are rampant in the country. No doubt this is a clear omission on the part of the Commission's report. It exemplifies the little attention paid to issues affecting the sexual health needs of children and adolescents despite the fact that the NHRC has appointed a Special Rapporteur for children. It must be noted that Nigeria has one of the worst cases of unsafe abortion in the region, ${ }^{60}$ which often lead to preventable deaths among young women.

Also, the HIV/AIDS prevalence in the country is very high among young people of 15-24 years, ranging between 3.5 (15-19 years) to 4.5 (20-24 years) percent. ${ }^{61}$ Contraceptives knowledge and use among adolescents and young people are generally poor, thus further compounding the situation. Several studies in the country have consistently reported poorknowledge and use of contraceptives, particularly emergency contraceptives, among young people. ${ }^{62}$ Similarly, child marriage is predominant in the northern part of the country which often leads to adverse situations such as early pregnancy and its associated complications. ${ }^{63}$ Although the government has approved a National Curriculum on Life Skills in schools, only a few states have actually adopted this curriculum. Most of the northern states - due to religious opposition - are yet to adopt this curriculum in their schools. Under Sharia law, operative in most of the northern states of Nigeria, sex outside of marriage including premarital sex is forbidden, hence there is strong opposition to providing sexual health information and services to adolescents in this part of the country. This presents a great challenge to realising the sexual and reproductive rights of adolescents in Nigeria. In addition, lack of youth-friendly health care services continues to militate against adolescents' access to comprehensive health care in the country. The few youth-friendly centres operating in the country are run by non-governmental organisations.

59 The Child Rights Act of 2003 incorporated most of the principles and rights contained in the Convention on the Rights of the Child as part of Nigerian law.

60 See Okonufua, F.E. et al., 'Assessing the Prevalence and Determinants of Unwanted Pregnancy and Induced Abortion in Nigeria', Studies in Family Planning, Vol. 30, No. 1, 1999, pp. 67-77.

61 Federal Ministry of Health (FMOH), Surveillance Report on HIV/AIDS and STIs in Nigeria, FMOH, Abuja, 2005, p. 12.

62 See, for instance, Arowojolu, A.O. and Adekunle, A.O., 'Perception and Practice of Emergency Contraception by Post-secondary Students in South West Nigeria', African Journal of Reproductive Health, Vol. 4, No. 1, 2000, pp. 56-65; and Okpani, A.O. and Okpani, J.U., 'Sexual Activity and Contraceptive use among Female Adolescents: A report from Port Harcourt, Nigeria', African Journal of Reproductive Health, Vol. 4, No. 1, 2000, pp. 40-47. 
With such a poor record, it is least expected of the NHRC to overlook the serious challenges to children's and adolescent's health in the country. Nigeria is a State party to a number of international and regional human rights treaties protecting adolescent health needs. For instance, Articles 24 of the CRC and 14 of the African Charter on the Rights and Welfare of the Child (African Children's Charter) ${ }^{64}$ - which have been ratified by Nigeria - both guarantee the right to health of children. The Committee on the International Covenant on Economic, Social and Cultural Rights (CESCR) has noted that the right to health also encompasses access to sexual and reproductive health related information and services. ${ }^{65}$ Also, the Committee on the CRC in its General Comments $3^{66}$ and $4^{67}$ has observed that States are under obligations to ensure access to sexual and reproductive health information and services for children and young persons within their jurisdictions.

In its 2005 Concluding Observations to Nigeria, the Committee on the CRC has expressed concerns over poor spending by the government on the health care needs of children. ${ }^{68}$ The Committee has similarly expressed its worries over lack of proper programmes to address the needs of children orphaned by HIV/AIDS in the country. ${ }^{69}$ It is to be noted that Nigeria is estimated to be home to about 1 million AIDS orphans. ${ }^{70}$

The Committee has further condemned lack of proper action to address issues such as early marriage, harmful traditional practices, sexual violence and knowledge gap on sexual and reproductive health on the part of adolescents in the country. ${ }^{71}$ The Committee expressed its disappointment at the lacklustre performance of the NHRC's Special Rapporteur on children's rights and called for financial and technical support for the Rapporteur. What this implies therefore, is that there is a gap with regard to safeguarding adolescents' sexual and reproductive rights in the country. Therefore, the NHRC needs to pay more attention to these areas of concerns expressed by the Committee on the CRC. Equally it needs to ensure the Nigerian government's commitments to addressing these issues urgently in line with its obligations under international law. As Murray rightly observes, NHRIs should be seen as national

\footnotetext{
64 African Charter on the Rights and Welfare of the Child, OAU Doc. CAB/LEG/24.0/49, 1990 (entered into force 29 November 1999).

65

UN Committee on CESCR, General Comment No. 14, The Right to the Highest Attainable Standard of Health, UN Doc. E/C/12/2000/4, 11 August 2000, para. 23.

Committee on the Right of the Child, General Comment No. 3, HIV/AIDS and the Right of the Child, UN Doc. CRC/GC/2003/3, Thirty-Second Session, 17 March 2003.

Committee on the Right of the Child, General Comment No. 4, Adolescents Health and Development in the Context of the Convention on the Right of the Child, UN Doc. CRC/GC/2003/4, Thirty-Second Session, May 2003.

8 Committee on the CRC, Concluding Observations: Nigeria 2005, UN Doc. CRC/C/146, adopted at the $38^{\text {th }}$ meeting held between 10-28 January 2005.

Ibidem, para. 716 .

Idem.

Ibidem, para. 715 .
} 
mechanisms through which they can ensure that decisions and recommendations of international bodies are properly implemented. ${ }^{72}$

Another human rights commission that is notable for its activism in the region is the South African Human Rights Commission (SAHRC). The SAHRC was established under section 184 of the 1996 Constitution $^{73}$ and South African Human Rights Commission Act of $1994^{74}$ with broad powers which include promotion and protection of both civil and political rights and social and economic rights in the country. ${ }^{75}$ It is empowered to carry out research and monitor violations of human rights in the country. As part of its promotional responsibility, the SAHRC has carried out a series of training programmes on human rights in the country. About 940 of such advocacy and training programmes relating to public education and community outreach which focus on issues relating to HIV/AIDS, equality, gender issues, children, social and economic rights and so on were carried out between 2005 and $2006 .{ }^{76} \mathrm{Also}$, the SAHRC has been involved in advocacy on institutionalisation of human rights in school's curriculum and has similarly engaged in education research on human rights.

In some of its reports the SAHRC has documented acute lack of basic amenities such as potable water, schools, health facilities, housing and hygienic environment essential for human dignity in some rural and informal settlements in the country. ${ }^{77}$ In line with its obligation under section 184(3) of the South African Constitution with regard to monitoring socio-economic rights in the country, the SAHRC has, since 1997, published annually, reports on the state of social and economic rights in the country. These reports cover rights relating to water, housing, health, social security, healthy environment and food. As regards the right to health care, the Commission, adopting the standard of reasonableness laid down by the court in the Grootboom Case, ${ }^{78}$ concluded in one of its reports that there existed gaps between enactment of legislation and development of policy on one hand and actual implementation of these laws and policies on the other hand. ${ }^{79}$ The Constitutional Court had held in

72

Murray, R., The Role of National Human Rights Institutions at the International and Regional Levels: The Experience of Africa, Oxford and Portland, Oregon, 2007, p. 12.

73

74

75

Constitution of Republic of South Africa, Act 108 of 1996.

The Human Rights Commission, Act No. 54 of 1994.

Section 184 of the Constitution, supra note 73.

South African Human Rights Commission (SAHRC) Annual Report 2005-2006, SAHRC, Johannesburg, 2006, p. 39.

See South African Human Rights Commission (SAHRC), Report of the Human Rights Week 2006, SAHRC, Johannesburg, 2006, pp. 9-14.

Government of the Republic of South Africa and Others vs Grootboom and Others 2000, (11) BCLR 1169 (Constitutional Court). In that case the Constitutional Court had held that government's policy on housing had failed the test of reasonableness as it did not address the need of those marginalised and in urgent need.

South African Human Rights Commission (SAHRC), Fifth Economic and Social Rights Report, SAHRC, Johannesburg, 2004, p. 5. 
that case that any governmental policy or law which fails to meet the urgent needs of vulnerable and marginalised groups would be regarded as being unreasonable. This decision is today regarded as the most authoritative decision on the scope of governments' obligations with regard to the enforcement of social and economic rights guaranteed under the South Africa Constitution. It can similarly be used to measure the effectiveness of government's laws and policies as regards adolescents in the country.

The SAHRC has particularly noted the decline in life expectancy from 56 years in 1996 to about 52 years in 2002 and projected further decline to about 47 at the end of $2005 .{ }^{80}$ It has also captured the rising infant mortality and maternal mortality rates in the country, attributing this to the HIV/AIDS-related deaths in the country. Indeed, the Commission reported that the most important challenge confronting the government is the devastating effect of the HIV/AIDS pandemic which has adversely overburdened the health sector in the country. ${ }^{81}$ In its 2006 report the SAHRC captured the dearth of health care workers in the country, deteriorating facilities in the care sector and challenges in accessing HIV treatment particularly by children. ${ }^{82}$

The SAHRC thus, recommended that the South African Government should take more concrete and targeted steps to ensure provision of health care facilities and services to those in rural areas, children orphaned by HIV/AIDS; the elderly and other disadvantaged groups in the country. It equally recommended that inequities be removed regarding access to health services in the country so as to give meaning to the constitutional right to universal and equal access to health.

However, the SAHRC fails to clearly pin-point the serious impact of the HIV/AIDS pandemic on the sexual and reproductive health of young women in the country. A report has shown that among young women (aged 15-24 years) in the country, about 13.7 per cent of them are living with HIV, while the figure for women within the ages of $20-24$ years is 28 per cent. ${ }^{83}$ This clearly calls for great concern. This high prevalence among young women cannot be isolated from the high rate of sexual violence in South Africa. Indeed, it has been reported that South Africa has one of the worst incidences of sexual violence in the world. ${ }^{84}$ The Committee on the CRC has expressed concern on the negative impact of HIV/AIDS, unintended pregnancies and sexual violence on the right of adolescents to enjoy their sexual and reproductive health in the country. ${ }^{85}$ Accordingly, the Committee has called on the South African Government to establish

$80 \quad$ Ibidem, p. 16.

$81 \quad$ Ibidem, p. 39.

82 SAHRC, Sixth Economic and Social Rights Report, SAHRC, Johannesburg, 2006, pp. 33-42.

83 See Department of Health South Africa, National HIV and Syphilis Prevalence Survey 2006, Department of Health, Pretoria; 2007, p. 9.

84 See Human Rights Watch, Scared at School: Sexual Violence against Girls in South African Schools, Human rights Watch, New York, 2001, p. 21 (there is no update on this report).

85 See, for instance, the Committee on the CRC, Concluding Observations: South Africa, UN Doc. $\mathrm{CRC} / \mathrm{C} / 94,26$ January 2000, para. 444. 
health care facilities - including those related to sexual and reproductive health that will be accessible to all adolescents without the need for parental consent where it is in the best interests of the child. ${ }^{86}$ The Committee has similarly suggested that government's health care programmes should pay special attention to children in the rural areas. ${ }^{87}$

The approach adopted by the SAHRC is highly commendable as it provides good avenues to monitor government's obligations under the Constitution and international and regional human rights treaties ratified by South Africa. The fact that the Commission is willing, not only to rely on internationally recognised indicators for monitoring right to health, but also legal standards to enable it to monitor the government's human rights performance, is a radical and commendable dimension of its obligation under section 184(3). Indicators refer to information - quantitative or qualitative - that helps in telling whether duty-holders' (governments) actions or policies are in compliance with their obligations under international law or whether rights-holders (citizens) are enjoying basic rights guaranteed under international law. ${ }^{88}$ Human rights indicators usually aim at providing information related to human rights norms and standards; reflect human rights concerns and principles and access and monitor the promotion and protection of human rights. ${ }^{89}$

Of the three human rights commissions examined so far, it is only the SAHRC that has shown readiness to employ the use of indicators in monitoring government's obligation to respect, protect and promote right to health care under the Constitution and international law. This appears to coincide with the suggestion of the CESCR Committee which has urged States parties to the Covenant to develop indicators and benchmarks for monitoring the right to health within their countries. ${ }^{90}$ The Committee on the CRC has similarly echoed this call in some of its concluding observations on States reports.91 Other authors, such as Green, have equally emphasised the importance of indicators in assisting government to realise its obligations under international law. ${ }^{92}$ This can particularly be useful in advancing the sexual and reproductive rights of adolescents. However, it should be pointed out that the SAHRC tends to show willingness to adopt indicators or legal standards to measure the right to health generally without paying attention to sexual and reproductive health needs of adolescents and women.

Idem.

Idem.

88 Greene, M., 'What We talk about When we talk about Indicators: Current Approaches to Human Rights Measurement', Human Rights Quarterly, Vol. 23, No. 4, 2001, pp. 1063-1096.

89 Malhotra, R. and Fasel, N., 'Quantitative Human Rights Indicators - A Survey of Major Initiatives', A paper presented at an Expert Meeting on Human Rights Indicators held between 11-13 March 2005 at Abo Akademi University, Turku, 2005, at p. 3.

90 See CESCR Committee, op.cit. (note 65), para. 57.

91 See, for instance, the Committee on the CRC, op.cit. (note 85), para. 427.

92 Green, loc.cit. (note 88), p. 1065. 
It is also to be noted that the SAHRC has been active in the submission of shadow reports to treaty monitoring bodies. One of such reports was the shadow report submitted to the Committee on the Convention on Elimination of Racial Discrimination (CERD). ${ }^{93}$ The report captures the challenges faced by the South African Government in overcoming racial discrimination in the country. Despite the abolition of the policy of Apartheid in the country, the government still struggles with completely eliminating racial discrimination from the fabric of society. This report submitted in line with the General Recommendation 28 of the CERD Committee, ${ }^{94}$ provides a good example of how an NHRI can effectively monitor government's commitments to promoting human rights within its jurisdiction. The CERD Committee in the above-mentioned General Recommendation 28 has enjoined NHRIs to 'assist their respective States in complying with their reporting obligations'. This position, as will be argued later, provides a good platform for measuring governmental commitment to advancing adolescents' sexual and reproductive rights.

It is clear from the above that some of the promotional activities of these NHRIs relate to sexual and reproductive health in general. The challenge, however, is that the needs of adolescents do not receive a lot of attention despite the fact that they are the most in need of such services in the countries mentioned above.

\subsection{PROTECTIVE MANDATE}

The protective mandate of NHRIs usually refers to the powers of such institutions to receive and attend to complaints. In some situations it may also refer to powers to investigate, settle disputes, achieve conciliation and hold public hearing on issues of human rights violations. It should be borne in mind that the powers of NHRIs to entertain complaints do not, in any way, equate them with a court of law; rather they perform this role only as a quasi-judicial body. Unlike the court of law, that can enforce its decisions, most of the decisions reached by NHRIs with regard to complaints handled are hardly enforceable. Therefore, it is important that an NHRI should not pretend to possess or even arrogate to itself judicial powers since in reality it lacks such powers. ${ }^{95}$ This quasi-judicial role is advantageous in the sense that it is less time consuming, flexible, often informal and usually non-confrontational, less expensive and more accessible to the poor and vulnerable groups in society than a

93 See South African Human Rights Commission (SAHRC), Shadow Report on South Africa's compliance with the provisions of the International Convention against all Forms of Racial Discrimination, SAHRC, Johannesburg, 2006, p. 12.

94 Committee on the Elimination of Racial Discrimination, General Recommendation 28, Follow-up to the World Conference Against Racism, Racial Discrimination, Xenophobia and Related Intolerance Adopted by Human Rights Treaty Bodies, UN Doc. HRI/GEN/1/Rev.6, 19 March 2002, para. 2(a).

95 See, for instance, the African Commission decision in the case of Ilesanmi vs Nigeria, Eighteenth Annual Activity Report of the African Commission on Human and Peoples' Rights, 2004-2005, Annex III, EX.CL/199(VII). 
court of law. ${ }^{96}$ It has been said, however, that the absence of quasi-judicial mandate in the activities of a NHRI should not render it less relevant in protecting human rights within its domain. ${ }^{97}$

The MHRC, discussed above, has as part of its protective mandate received and treated complaints, provided legal services to complainants, initiated court interventions on matters falling within its entire scope of mandates and examined judicial, legislative and administrative decisions for conformity with essential principles of human rights. ${ }^{98}$ In total, the Commission received 1,136 complaints in 2004 dwelling on diverse issues such as labour rights, access to justice, unlawful detention, property rights and children's rights. Of the total number of complaints received, 163 were sustained for further investigations, 66 resolved through public and investigative hearings, mediation and negotiations, 117 still pending for investigation, 138 referred to other institutions with appropriate jurisdiction and 146 received advice of the MHRC. ${ }^{99}$

With regard to children's rights, the MHRC received a total of 50 cases on this issue and 17 of them were successfully resolved while seven were referred to other bodies for attention and six were advised to seek another form of legal redress. Although he successfully resolved cases representing less than 50 percent of the total complaints involving violation of children's rights, it is still a commendable effort. It should be noted, however, that in resolving complaints brought before NHRIs it is not the volume of complaints resolved that matters; rather it is the effectiveness of the remedy provided that is important.

The NHRC is empowered under the Act establishing it to investigate human rights abused and provide relief for victims of such human rights violations. Any person whose rights have been violated may lodge a complaint with the Commission seeking redress for the violation of such rights. Such a complaint may relate to violations of both civil and political rights and social and economic rights The Commission received a total number of 551 complaints in the year 2005. ${ }^{100}$ Of this number of complaints lodged before the Commission, 476 (representing about 86 percent of all the cases) were admissible while 75 of the cases (representing about 14 percent) were rendered in admissible. ${ }^{101}$ Of the total number of admissible complaints about 319 were successfully concluded while 157 were pending. ${ }^{102}$

\footnotetext{
96 Burdekin, B., Human Rights Commission', A paper presented at a workshop on the $2^{\text {nd }}$ European Meeting of National Institutions held in Paris, 7-9 October 1991, p. 120; and Dankwa, E.V.O., 'Promotion of Human Rights and National Institutions, An Example from Ghana', Africa Legal Aid Quarterly, July-September 1997.

97 See Okafor and Agbakwa, loc.cit. (note 25), p. 684.

98 See MHRC, op.cit. (note 37), p. 7.

99 Idem.

100 NHRC, op.cit. (note 57), p. 23.

101 Idem.

102 Idem.
} 
From 1996 when the NHRC came into being till 2005 a total number of 3, 536 complaints have been received by the Commission out of which about 2,536 were admissible and 990 were declared inadmissible. With regard to the admissible complaints, 1,175 were successfully concluded whereas 1,361 complaints were regarded as pending. This is a clear indication that the NHRC needs to redouble its efforts in order to be more effective in its handling of complaints lodged before it. The nature of the complaints brought before the Commission varies, ranging from extra judicial killing to unlawful detention, disobedience of court orders, domestic violence, communal clashes, non-payment of workers' benefits and entitlements, threat to life and so on.

As seen from the types of complaints lodged before the Commission, it would appear that the majority of these cases centre on the violations of civil and political rights. Indeed, complaints on unlawful arrest and detention top the lists of the types of complaints received by the Commission. Only very few complaints on social and economic rights were received and even fewer touching on sexual and reproductive health, such as child abuse or domestic violence. It has been reported of the total number of complaints received for the year 2005 alone, the compromised about five percent of complaints on child abuse and about 10.5 percent of complaints concerned domestic violence. Considering the fact that the Commission has appointed Special Rapporteurs for children and women and gender related matters, one would have expected a better result in terms of the number of complaints lodged with the Commission in these areas.

The poor or low utilisation of the Commission's complaints mechanism on issues relating to adolescents' sexual and reproductive rights is an indication of existing gaps between the protective mandate of the Commission and its ability to advance adolescents' sexual and reproductive rights within the country. The fact, that sexual and reproductive rights of adolescents are continuously violated without adequate means of redress in the country, clearly brings to the fore the need for more attention in this area. Perhaps the Commission might need to embark on awareness programmes regarding its activities targeting community groups, children and adolescents, community leaders and the general public.

As for the SAHRC remarkable work has been done as regards its protective mandate. For instance, at the end of 2005, 2,767 complaints were received by the Commission's head office out of which 957 were valid, while 8,943 complaints were received at the provincial offices out of which 2,946 were regarded as valid. In all, from a total of 3,903 complaints validly received by the Commission, 2,107 were successfully dealt with. ${ }^{103}$ Additionally, the Commission has been able to successfully litigate important cases touching on various areas including rights of women and children to inherit under customary law. The Commission was instrumental to the filing of the land mark

103 South African Human Rights Commission (SAHRC), Annual Report 2005-2006, SAHRC, Johannesburg, 2006, p. 27. 
case involving Bhe and Others vs Magistrate, Khayelitsha and Others, ${ }^{104}$ in which the Constitutional Court struck down part of the Black Administration Act and Intestate Succession Act that were found to be discriminatory on the basis of race and gender due to the fact that they deny female spouses, common law wives, girl children and children born out of wedlock from inheriting under customary law.

On other occasions the Commission has played the role of an amicus curie (friend of the court) during the hearing of important cases by the court. A good example of this was the South African Constitutional Court's ground breaking decision in the Grootboom Case. ${ }^{105}$ This kind of a situation allows the Commission to bring its expertise into play with regard to specific issues dealing with human rights of the people. It also exemplifies willingness on the part of the Commission to live up to its crucial roles of safeguarding human rights in the country. This approach by the Commission is quite commendable as it allows the Commission to play the role of a watch-dog in society. It is also a mark of a truly committed and independent institution dedicated to protecting human rights in society.

While it is admitted that the Bhe Case indirectly touches on the rights of children and adolescents the Commission is yet to specifically litigate on a case bearing directly on adolescents' sexual and reproductive rights. Moreover, the Commission missed a great opportunity to partake in advancing children's rights when it failed to act as an amicus during the epoch making case of Minister of Health and others vs Treatment Action Campaign and others. ${ }^{106}$ This certainly can be described as a case of missing in action when it mattered most. In that case, the court held that government policy that limited provision of antiretroviral drugs for prevention of mother-to-child transmission of HIV to 18 sites was unreasonable and did not meet the needs of children as envisaged by the Constitution. This decision can be invoked to hold the government accountable for its failure to meet the sexual and reproductive health needs of adolescents in the country. But one must commend the SAHRC for its approach of initiating test cases before the national courts. It is a bold step worthy of emulation by other NHRIs in the region. Murray has further suggested that the filing of cases should not be limited to national courts but can be extended to include regional and international tribunals. ${ }^{107}$ Indeed, a precedent already exists in this respect: the National Human Rights Commission of Chad has filed a case before the African Human Rights Commission alleging massive violations of human rights within the country. ${ }^{108}$ This precedent can be applied to violations of sexual and reproductive rights of adolescents as well.

104

\section{5}

106

107

108

2004 (2) SA 544 (Constitutional Court).

Government of the Republic of South Africa and Others vs Grootboom and Others, supra note 78. 200210 BCLR 1033 (Constitutional Court).

Murray, op.cit. (note 72), p. 12.

See African Commission on Human and Peoples' Rights, Commission Nationale des Droits de l'Homme et des Libertés vs Chad, 1997, Comm. No. 74/92, (2000) African Human Rights Law Reports 
In recent times the SAHRC has organised a number of public hearings and inquiries in the country on different issues such as right of indigenous people, xenophobia, right to health, same sex relations, access to housing and so on. A major importance of a public hearing is the fact that it vividly captures human rights violations by allowing victims of such violations to narrate their experiences through the eyes of the public. It is a technique often used to emphasise the nature and extent of human rights violations and to draw attention of both policy makers and the public to such violations.

As seen from the activities of these NHRIs, several steps have been taken to ensure protection of human rights within their jurisdictions. However, very few of these steps have been directed towards promoting and protecting sexual and reproductive rights of adolescents. The modest successes recorded over the years by NHRIs in Africa in the execution of their mandates have not been effectively employed to address issues relating to the need of adolescents in the region. Thus, in the next sections of this article, possible limitations of NHRIs to advancing adolescents' sexual and reproductive rights and how the experience of NHRIs can be channeled towards meeting the needs of adolescents in the region are considered.

\section{LIMITATION OF NHRIS TO ADVANCING ADOLESCENTS' SEXUAL AND REPRODUCTIVE RIGHTS IN AFRICA}

As noted above, NHRIs in Africa have the potential to advance sexual and reproductive rights of adolescents in the region; however, their ability to do this is often impeded by a number of challenges including poor funding, lack of independence, incompetent personnel, poor relationship with civil society among others. Some of these challenges will be considered in this section.

\subsection{POOR FUNDING}

There is no gainsaying the fact that proper funding is sine qua non to an effective and independent NHRI. Today, one of the greatest challenges facing NHRIs in Africa is poor funding. In some African countries, the finances needed for the day to day running of NHRIs are either not available or are tied to the apron strings of the executive. This no doubt portends great danger to an independent NHRI. ${ }^{109}$ The corollary of this is poor performance and inability of these institutions to meet the desired needs of the populace especially vulnerable groups as children and adolescents. The Paris Principles explicitly declare that 'national institutions shall

109 Smith, A., 'Unique position of National Human Rights Institutions', Human Rights Quarterly, Vol. 28 , No. 4, 2006, pp. 904-946. 
have an infrastructure which is suited for the smooth conduct of its activities, in particular adequate funding.' ${ }^{110}$ Funding in this respect relates to both financial and administrative independence of NHRIs.

The Nigerian Human Rights Commission in one of its reports has noted that one of the greatest challenges to realising its mandates include lack of adequate funding. ${ }^{111}$ A similar constraint was echoed by the Malawi Human Rights Commission in one of its reports where the Commission lamented inadequate funding of its activities by the Malawian Government. ${ }^{12}$ Often due to lack of funding these institutions are unable to recruit capable hands to ensure good results with regard to their activities. It is therefore not surprising, that virtually all of the three NHRIs examined above complained of shortages of qualified personnel. This can lead to poor performance on the part of these institutions, since they are unable to employ capable hands in the area of promoting and protecting adolescents' sexual and reproductive rights. The South African Constitutional Court in the case of New National Party of South Africa vs Government of South Africall ${ }^{113}$ has unanimously approved the need of an electoral institution to be financially and administratively independent. Although this decision specifically relates to an electoral body, the principles of law enunciated here can equally apply to NHRIs.

Whilst lack of adequate funding of NHRIs in Africa has been attributed sometimes to the general pervading poverty in the region, it has been found that in some situations governments have deliberately withheld funding to NHRIs in order to render them impotent. ${ }^{114}$ Although some of the NHRIs in the region receive funding from other sources such as donor agencies, the greatest part of their funding comes from their governments. Perhaps one of the ways out of this problem is by making the legislature the proper body to determine the budget of NHRIs. This can be done by creating a consolidated fund for which NHRIs can draw their finances. ${ }^{115}$ Certainly, a situation where NHRIs are made to go caps in hands to the executive or any of its departments, to enable them carry out their activities, does not augur well for the credibility and independence of these institutions. Realising the importance of adequate funding to the independence of these institutions, the Committee on the CRC has called on States to ensure that NHRIs are provided with necessary infrastructure and are not starved of funds - particularly in monitoring children's rights within their jurisdictions - so

110 Idem.

111 See NHRC, op.cit. (note 57), p. 38.

112 See MRHC, op.cit. (note 37), p. 29

113 New National Party of South Africa vs Government of the Republic of South Africa, (5) BCLR 489 (Constitutional Court) (1999).

114 See Human Rights Watch, Protectors or Pretenders? Government Human Rights Institutions in Africa, Human Rights Watch, Washington, 2001, available at: www.hrw.org.

115 See Matshekga, J., "Tootles Bulldogs? The Human Rights Commissions of Ugandan and South Africa: A Comparative Study of their Independence', African Human Rights Law Journal, Vol. 2, No. 1, 2002, pp. 68-91. 
that they can perform their duties as expected. ${ }^{116}$ According to the Committee: "The mandate and powers of national institutions may be meaningless, or the exercise of their powers limited, if the national institution does not have the means to operate effectively to discharge its powers.' ${ }^{17}$

\subsection{APPOINTMENT OF PERSONNEL}

The success or otherwise of a NHRI is hinged on the calibre of its personnel. A NHRI that is made of governments' apologists and devotees will hardly live up to the expectations of the people. Therefore, if a NHRI is to efficaciously carry out its protective and promotional mandates, particularly with regard to the emerging issue of sexual and reproductive rights of adolescents, then it is imperative that its personnel must be made of diverse background. Indeed, this point constitutes an essential concern of the drafters of the Paris Principles. The Principles have emphasised the need for pluralism of members of a NHRI that may be derived from academic institutions, civil society groups or the private sector. In addition to this, NHRI members should be able to display good understanding of international human rights issues or principles and should enjoy a secured tenure. However, one report has observed that whilst appointment of members of NHRIs in Africa appears to be diverse, many of the members lack good understanding of international human rights principles. ${ }^{118}$ This can cause some draw backs to these institutions. In addition, it is desirable that NHRIs should appoint members with experience on children's rights issues so as to ensure adequate protection of the rights of children and adolescents. ${ }^{119}$ Moreover, in a religiously diverse country as Nigeria, it may be necessary for the NHRC to be made up of people knowledgeable in both customary law and sharia law. In some situations such as in Malawi, appointment of members of these institutions is often for a short period. ${ }^{120}$ This has been criticised for being inadequate and unsatisfactory as it would deny members the opportunity to gain necessary experience and may stall continuity in the works of these institutions. ${ }^{121}$

In other situations it has also been found that the executive has manipulated the appointment of the head of NHRIs - a practice, which can create serious credibility problem for the institution. A case at hand is that of the removal of the former head and the subsequent appointment of the incumbent head of the NHRC. It is believed that the appointment of the incumbent was made by the erstwhile president of Nigeria

116 Committee on the CRC, General Comment No. 2, op.cit. (note 53), para. 10.

117 Ibidem, para. 11.

118 See Human Right Watch, op.cit. (note 114).

119 Committee on the CRC, op.cit. (note 53), para. 12.

120 See section 5 of the Malawi Human Rights Commission Act which provides that a commissioner shall be appointment for a period of three years and may be reappointed where necessary.

121 See Nigerian Human Rights Community Report The People $v$ Attorney General In the Mater of the Nigerian Human Rights Commission, Nigerian Human Rights Community, Abuja, 2006, p. 15. 
Chief Obasanjo contrary to the Paris Principles as it was done surreptitiously without adequate consultations with civil society groups and other stakeholders. Many civil society groups within and outside the country protested against the circumstances under which the former head was removed. ${ }^{122}$ It was believed that his vocal condemnation of some government's actions was the reason for his removal. This situation has been denounced in the international arena. The Special Representative to the UN Secretary General on Human Rights Defenders and the Special Rapporteur of the African Commission on Human and Peoples' Rights on Human Rights Defenders have both condemned this action. ${ }^{123}$ Indeed, in reaction to this, the international body of human rights institutions has refused to recognise this appointment and even defer re-accreditation of NHRC to this body pending the time the Nigerian Government furnished it with adequate information on this issue. ${ }^{124}$

Undue interference, as seen from the Nigerian example, in the activities of NHRIs can cripple their effectiveness, impugn their credibility and prevent them from carrying out their legitimate roles of monitoring human rights violations without fear or favour within their jurisdictions. This scenario tends to affect more sexual and reproductive rights of vulnerable groups as children and adolescents which are often accorded little or no priority by African governments. It has been noted that NHRIs in Africa are potentially vulnerable to executive interference or manipulation. ${ }^{125}$ Unless the executive arm of government in African countries ceases to see NHRIs as extensions of its arm, then NHRIs in Africa will remain veritable tools of manipulation in the hands of the executive and politicians as well. In such situations the independence of these institutions is easily eroded, and their commitment to protecting human rights, diminished. It is important that the executive should liaise with civil society groups in appointing members and heads of NHRIs in their countries. This will ensure independence and credibility of these institutions

\subsection{RELATIONSHIP WITH CIVIL SOCIETY GROUPS AND OTHER INSTITUTIONS}

One of the challenges facing NHRIs in Africa is their inability to relate effectively with civil society groups, government's agencies and other institutions in their country. Although it should be noted that this challenge is gradually being overcome, NHRIs in Africa can do better than what presently exists. The Paris Principles enjoin NHRIs to form a good working relationship with civil society organisations

122 Hatchard, J., 'The Human Rights Commission Act of 1998 (Malawi)', Journal of African Law, Vol. 43, No. 2, 1999, pp. 253-257.

123 Ibidem, pp. 13-14.

124 See International Coordinating Committee of National Institution for the Promotion and Protection of Human Rights Report on the $19^{\text {th }}$ Session held on 22 March 2007 in Geneva. 
within their jurisdictions. ${ }^{126}$ In addition the Abuja Guidelines require NHRIs to foster a cordial relationship with governmental bodies. ${ }^{127}$ Working with civil society organisations, particularly human rights NGOs and community based organisations can be advantageous in the sense that these organisations can form effective links between national institutions and individuals or groups who are politically, socially or economically marginalised. ${ }^{128}$ For example, a good working relationship with community based organisations can provide NHRIs with first hand information in rural areas with regard to the sexual and reproductive health needs of adolescents and the strategies required to meet these needs. Since community based organisations and other NGOs are closer to the people they serve than NHRIs, they are able to identify the people's needs and can similarly provide possible solutions for meeting these needs. This can easily complement the work of NHRIs.

Okafor and Agbakwa have, however, argued that the relationship between NHRIs and NGOs should be seen as two sides of a coin. ${ }^{129}$ That is, whilst a NHRI can benefit from the experience of NGOs, the latter can similarly benefit from the expertise of the former. They contend that it will be wrong to always assume that NGOs are 'resources' whilst NHRIs are 'agents'. Such a one-sided view of this relationship can be misleading, since in some situations NGOs can drink from the fountain of experience of NHRIs.

Also, fostering a good relationship with governmental institutions and bodies can facilitate quick and positive results for NHRIs. For instance, where an NHRI enjoys a good working relationship with the legislature this can enhance good response to law reforms and prevent undue delay to the approval of funding for NHRIs. If the legislature is very conversant with the activities and challenges of NHRIs it will become easy for it to give the necessary supports to such NHRIs. An NHRI that enjoys the full support of the legislature will be able to initiate bills beneficial to the health needs of adolescents and equally ensure their passage into law.

However, while it is desirable that a NHRI should relate with governmental agencies and non-governmental organisations, it must not been seen to be leaning too much toward either of these institutions lest it stands the risks of being accused of compromising its independence. As Smith correctly observes, a NHRI that is too close to the government will be regarded as a puppet of the government. ${ }^{130}$ On the other hand, if a NHRI is seen to be too close to NGOs it may be regarded as being 'proNGO' ${ }^{131}$ Therefore, a NHRI should be able to strike a balance and be able to determine

\footnotetext{
126 Paris Principles, supra note 22, C 7.

127 Abuja Guidelines on the Relationship between Parliaments, Parliamentarians and Commonwealth National Human Rights Institutions (Abuja Guidelines, March 2004).

128 International Council of Human Rights Policy, op.cit. (note 32), p. 8.

129 Okafor and Agbakwa, loc.cit. (note 25), p. 690.

130 Smith, loc.cit. (note 109), p. 910.

131 Idem.
} 
when it is crossing the lines in its relationships with these institutions. The challenge however, is that most NHRIs often perceive NGOs as antagonists and legislatures as potential threats to their independence thus leading to a hostile relationship between some NHRIs and these bodies.

Additionally, it is ideal for NHRIs to relate with regional or international human rights institutions. For example, NHRIs in African can learn a lot from the activities of the regional human rights body - the African Commission. Although the commission was severely berated for its non-performance by critics at its initial stage, ${ }^{132}$ however, of recent the Commission has played important roles in the promotion and protection of human rights in Africa. For instance, the Commission through its complaints procedure, has developed landmark jurisprudence with regard to the rights guaranteed under the African Charter. ${ }^{133}$ Similarly, the Commission through its promotional mandate has been making a remarkable contribution to the advancement of human rights in the region. Fortunately, the Commission during its $24^{\text {th }}$ Ordinary Session in 1998 has accorded recognition to NHRIs in the region by granting them observer status. This is a welcome development and NHRIs can positively explore this by tapping into the rich experience of the African Commission in promoting and protecting human rights in the region. It has been rightly observed that network with regional institutions by NHRIs can serve as a bulwark against unfriendly governmental attacks on an NHRI. ${ }^{134}$

\subsection{ACCOUNTABILITY OF NHRIs}

Since NHRIs are creations of law, it is, therefore, necessary that they be accountable to governmental bodies such as the parliament. Indeed, most NHRIs are required to submit annual reports to the legislative or executive arm as a routine procedure to render account of their stewardship. ${ }^{135}$ However, not many NHRIs have lived up

132 See, for instance, Odinkalu, C.A., 'Analysis of Paralysis or Paralysis by Analysis? Implementing Economic, Social, and Cultural Rights under the African Charter on Human and Peoples' Rights', Human Rights Quarterly, Vol. 23, No. 2, 2001, pp. 327-369. See also Welch, C.E., 'The African Charter and freedom of expression in Africa', Buffalo Human Rights Law Review, Vol. 4, No. 2, 1998, pp. 103-114.

133 See, for examples, the Commission's decision in: African Commission on Human and Peoples' Rights, Social and Economic Rights Action Centre (SERAC) and Another vs Nigeria, 2001, African Human Rights Law Review 60; and African Commission on Human and Peoples' Rights, Purohit and Moore vs The Gambia, Communication $241 / 2001,16^{\text {th }}$ Annual Activity Report of the ACHPR, decided at the 33rd Ordinary Session of the African Commission held from 15-29 May 2003 in Niamey, Niger.

134 Kjaerum, M., National Human Rights Institutions: Implementing Human Rights, Danish Center for Human Rights, Copenhagen, 2003, p. 8.

135 Besselink, L.F.M., 'Types of National Institutions for the Protection of Human Rights and Ombudsman Institutions: An overview of Legal and Institutional issues', in: Hossain, K. et al. (eds), Human Rights Commissions and Ombudsman Offices: National Experiences throughout the World, Kluver Law International, The Hague, 2000, pp. 157-165. 
to this reporting responsibility, either because the reports are submitted late or are hardly detailed. ${ }^{136}$ But, beyond this form of accountability, an important limitation to the activities of NHRIs in Africa is their inability to be accountable to the people they serve. This type of accountability has been referred to as public or popular accountability. ${ }^{137}$ It is a very important part of an NHRI's existence as it can determine the level of support or scepticism an NHRI will receive from the public. One of the most visible ways of being accountable to the public is through publications of reports detailing the activities of an NHRI. Such reports must be timely and must reflect diverse areas of human rights violations in a country. Additionally, the reports must be widely distributed within every nook and cranny of a country including rural areas in accessible languages.

All three NHRIs mentioned have been producing reports with regard to their activities. It is noted though, that the NHRC has not been very consistent in this area. Moreover, it took the Commission a long time before it could come up with a formal report on its activities and could only produce a report on human rights situation in the country for the first time in 2006. This kind of situation tends to create some doubt in the minds of the public concerning the seriousness or commitment of an NHRI in protecting and promoting human rights in a country.

A worrisome aspect of the reporting style of these institutions is the fact that most of their reports are hardly distributed widely to reach all and sundry. Although attempts are being made by these institutions to translate their reports into local languages it does not appear that these efforts are yielding fruits as many people still are not aware of the activities of these institutions. ${ }^{138}$ One thing that can account for this poor response from the public could be the lack of effective use of the media by these institutions. Whilst one may not expect NHRIs to reach every nook and cranny of their countries, taking into cognizance the financial challenges they face, it will be expected that at least a considerable number of people should be aware of the activities of these institutions. Where people are not aware of the existence of an NHRI, human rights violations cannot be reported and thus cannot be redressed. The people that are particularly affected are the vulnerable groups, mainly children and adolescents, whose sexual and reproductive rights are constantly in danger of being violated.

Public accountability also involves the capability of an NHRI to address sensitive human rights violations regardless of whose ox is gored. Where necessary an NHRI must be able to report objectively regarding human rights violations occasioned by the government or any of its agencies or even by powerful individuals in the country. Equally NHRIs must focus on reporting violations experienced by the powerless or

136 Hatchard, J. et al., Comparative Constitutionalism and Good Governance in the Commonwealth: An Eastern and Southern perspective, Cambridge University Press, Cambridge, 2004, p. 219.

137 See Smith, loc.cit. (note 109), p. 938.

138 See, for instance, Matshekga (loc.cit. (note 115), p. 70) lamenting the fact that most people are not aware of the activities of the SAHRC. 
voiceless (particularly, children and adolescents in rural areas, in custody, refugee and migrant children, street children and so on) in society. This is when such an institution can be seen as performing its functions impartially and responsibly. As one study has shown, not many NHRIs in Africa can be said to have lived up to this expectation. ${ }^{139}$ In addition NHRIs must be accessible to all and in particular the vulnerable groups. Accessibility relates to geographical and physical proximity of these institutions to the people they serve especially women and children in rural areas, children in detention, children from minority or indigenous groups, children with disabilities and children living in poverty. ${ }^{140}$

\section{OPPORTUNITIES FOR NHRIS TO REALISE ADOLESCENTS' SEXUAL AND REPRODUCTIVE RIGHTS}

No doubt many NHRIs in Africa can be said to have come of age in their roles of promoting and protecting human rights in the region. From the discussion above on the three NHRIs, it is obvious that the contributions of these institutions to advancing human rights in the region cannot be overlooked. The various experiences of these institutions in addressing human rights situations in their countries can serve as potential catalysts for promoting and protecting adolescents' sexual and reproductive rights in the region.

The adoption of the use of Special Rapporteurs by the NHRC can serve as an important vehicle for realising adolescents' rights in that country. A Special Rapporteur is often charged with investigating human rights violations, ensuring appropriate remedy for such violations and raising the profile of a specific human rights issue. The Special Rapporteur on children appointed by the NHRC could have been involved in investigating human rights violations experienced by children and adolescents in the areas of female genital mutilation/cutting, sexual violence, poor knowledge and lack of information on the use of contraception and others. Similarly, this Rapporteur can help in drawing attention of the government to the seemingly poor focus on adolescents' sexual health needs via publication of reports on this issue. It is a well-known truth that investigations and reports of human rights violations remain one of the most significant functions of NHRIs and essential aspects of their protective mandates. ${ }^{141}$

Several examples exist under international law with regard to the importance of appointing Special Rapporteurs. For instance, the UNSecretary-General's independent expert (whose responsibilities are almost akin to that of a Special Rapporteur) appointed on violence against children has conducted various research with regard

\footnotetext{
139 See Human Rights Watch Report, op.cit. (note 114).

140 Committee on the CRC, op.cit. (note 53), para. 15.

141 Smith, loc.cit. (note 109), p. 917.
} 
to violence against children worldwide and has published a report documenting the nature and extent of violence experienced by children around the world. ${ }^{142}$ The report particularly identified five settings where violence against children occurs which include the family, schools, alternative care institutions and detention facilities, places where children work, and in their communities. ${ }^{143}$ These actions have elicited reactions and commitments from governments all over the world to put an end to violence (including sexual violence) against children in their countries. Also, the appointment, for the first time, of the Special Rapporteur on the right to health in 2002 by the UN, has led to an increasing recognition of the right to health in most constitutions of the world. ${ }^{144}$ Through his numerous activities over the years, the Special Rapporteur has been able to draw the attention of the world to certain health issues such as neglected diseases, maternal mortality, access to medicine for the poor, sexual and reproductive rights of vulnerable groups and so on. Furthermore, under the African human rights system, the appointment of a Special Rapporteur on prisons has led to better attention for prisons conditions and the need to safeguard prisoners' rights in the region. ${ }^{145}$ Similar positive results could have been obtained had the appointment of the Special Rapporteur on children by the NHRC been put into effective use. Undoubtedly, NHRIs in the region can learn a lot from these examples and apply them to advance adolescents' rights within the region.

The establishment of a special unit for children by the MHRC is no doubt a potential avenue for advancing adolescents' sexual and reproductive rights in the country. However, this unit has not been put into effective use so as to achieve its desired results. The unit could have produced reports focusing on violations of rights experienced by children and adolescents in the country. More importantly, the unit through aggressive advocacy and enlightened programmes could have drawn attention to the unmet sexual and reproductive needs of adolescents in the country. Also, this unit could have initiated a cordial working relationship with NGOs specialising on adolescents issues in the country. Such a relationship can help in better understanding the nature of human rights violations experienced by adolescents and what could be done to address these violations. It could at the same time afford the MHRC an opportunity to complement the works of these NGOs through the expertise of the special unit for children. Experience from the activities of the three NHRIs examined above has shown that they have been working with NGOs in their respective countries. Such a

142 See Pinheiro, P.S., 'World Report on Violence Against Children', UN Secretary-General's Report on Violence Against Children, United Nations, Geneva, 2006, pp. 1-18.

143 Ibidem, p. 7.

144 See The Right of Everyone to the Highest Attainable Standard of Physical and Mental Health, Report of the Special Rapporteur, P. Hunt, submitted in accordance with Commission Resolution 2002/31, UN ESCOR, 59th Sess., UN Doc. E/CN.6/2003/58, February 2003.

145 See, for instance, Viljoen, F., 'The Special Rapporteur on Prisons and Conditions of Detention in Africa: Achievements and Possibilities', Human Rights Quarterly, Vol. 27, No. 1, 2005, pp. 125-171. 
relationship should be developed further and perhaps broadened so as to pay attention to the sexual and reproductive health needs of adolescents in their countries

The use of indicators by the SAHRC to measure government's accountability with regard to safeguarding human rights is another veritable tool that can help in advancing the sexual and reproductive rights of adolescents in that country. As earlier stated indicators can assist in ensuring governments' commitment to promoting and protecting human rights within their domains. The SAHRC, in conjunction with non-governmental organisations can come up with a clearly defined and realistic set of indicators with regard to the sexual and reproductive health needs of adolescents in the country. Such indicators should take into cognisance the peculiar nature of a State. This set of indicators can assist the government in complying with its obligations under the CRC. Indeed, developing a set of indicators for adolescents' sexual and reproductive rights will complement the work of treaty monitoring bodies such as the Committee on the CRC and the Expert Committee on the African Children's Charter. On several occasions, the Committee on the CRC has lent its support for such an approach. ${ }^{146}$ Equally, the CESCR Committee has reiterated this in its General Comments No. $10,{ }^{147}$ on National Human Rights Institutions and on the Right to Health No. $14 .{ }^{148}$ Whilst it is admitted, as observed by Hunt, ${ }^{149}$ that indicators may not always provide clues as to human rights violations, they no doubt remain important in measuring government's commitment to promoting and protecting human rights.

Furthermore, the submission of a shadow report by the SAHRC to the CERD Committee can become a good precedent for submission to other treaty monitoring bodies particularly the Committee on the CRC. The SAHRC can prepare a report outlining the challenges encountered by adolescents in realising their sexual and reproductive rights within South Africa. Shadow reports are very important in the sense that they tend to provide an objective and unbiased analysis of human rights situation within a country. In most cases official reports to treaty bodies tend to exaggerate government's performance and underplay serious human rights violations, thus giving a false impression that all is well. It should be noted also that shadow reports provide treaty monitoring bodies with balanced information to enable them to reach a logical and reasonable assessment of a government's obligation under a specific human rights treaty. Shadow reports can also help a government to be alive to its human rights obligations under ratified treaties.

Where a government is aware that an independent body or group is monitoring its activities and is likely to submit alternative reports to a treaty monitoring body,

\footnotetext{
146 See Committee on the CRC, op.cit. (note 85), para. 427.

147 See the CESCR Committee, General Comment No. 10, The Role of National Human Rights Institutions in the Protection of Economic, Social and Cultural Rights, UN Doc. E/1999/22, 14 December 1998, at para. 18.

148 CESCR Committee, op.cit. (note 65), para. 57.

149

Hunt, P., Human Rights Law and Practice, Butterworths, London, 1999, p. 115.
} 
the government tends to be more cautious and realistic with regard to its actions and claims. NHRIs can draw attention of treaty monitoring bodies to a specific or neglected area of adolescents' sexual and reproductive rights through preparation of shadow reports to counter government's reports to the Committee on the CRC. It must be borne in mind that NHRIs are not only expected to submit shadow reports where necessary, but also to monitor implementation of concluding observations or comments made by treaty monitoring bodies with regard to States' reports submitted to them. Where a treaty monitoring body has identified a gap in fulfilment of human rights obligations, an NHRI has the duty to follow up on this aspect with a view to ensuring improvement by the government on this aspect. For instance, where the Committee on the CRC raised some concerns with regard to Nigeria's non-compliance with its obligation under the CRC to respect, protect and fulfil the rights of children, it will be expected of the NHRC to carefully monitor government's response to these queries and how the government intends to correct these short comings in its next report.

However, many NHRIs in Africa are really lagging behind in preparation and submission of shadow reports to treaty monitoring bodies. With the rare exception of the SAHRC mentioned above, NHRIs in the region do not usually appreciate the significance of preparing a shadow report. This may be attributed to the ambiguity regarding the true nature of roles to be played by these NHRIs in this respect. ${ }^{150} \mathrm{Or}$ perhaps this may be that most of these NHRIs are playing safe and do not want to be seen as confrontational to the government that have established them and sometimes provide them with necessary funding. As shown above, one essential prerequisite for the effective functioning of NHRIs is the ability of these institutions to operate independently of State control.

Also, the report of the SAHRC, which gives detailed attention to issues relating to the right to health including sexual and reproductive rights of children and adolescent serves as a good model for advancing adolescents' sexual health needs in the region. The SAHRC Fifth Report on Social and Economic Rights documents extensively the situation of the right to health in South Africa. Some parts of the report focus on issues relating to children and adolescent such as infant mortality rate, access to contraception, unwanted pregnancy and access to legal abortion and so on. In the same manner, the report of the MHRC focusing on the impacts of harmful customary practices on women in the country is equally commendable. These are welcome developments worthy of emulation by other NHRIs in the region. Publication of human rights reports is a way of publicising forms of discrimination and human rights violations in a country. ${ }^{151}$ In future such reports can be devoted specifically to the challenges adolescents encounter with regard to their sexual and reproductive health in these countries.

\footnotetext{
$150 \quad$ See Murray, op.cit. (note 72), p. 16.

151 Ibidem, p. 4.
} 


\section{CONCLUSION}

No doubt NHRIs are key players in the realisation of peoples' rights, particularly the rights of vulnerable groups such as children and adolescents. As seen above, some NHRIs in Africa are increasingly making attempts at advancing human rights within their countries. However, more efforts would seem to be required with regard to issues relating to the sexual and reproductive rights of adolescents in the region. Experience with the three mentioned NHRIs has shown that adolescents' sexual and reproductive rights have not been made a priority in their activities. This is indeed ironic, considering ample evidence pointing to the fact that adolescents carry a greater burden of sexual and reproductive ill health in the region and particularly in these countries. It is therefore necessary, as suggested by Okafor and Agbakwa, that NHRIs should pay more attention to the 'voices of suffering' (vulnerable groups) in their countries. ${ }^{152}$

From the discussion on the three NHRIs, it is obvious that they are not living up to the consensus statement agreed upon at the Lomé Declaration on NHRIs, where it was agreed that NHRIs in Africa should pay more attention to issues affecting women's and children's rights including the negative impacts of the HIV/AIDS pandemic. ${ }^{153}$ At both the international Conference on Population and Development (ICPD) ${ }^{154}$ and the Fourth World Conference on Women (FWCW) ${ }^{155}$ representatives of governments of the world agreed to pay great attention to the health of adolescents and to ensure that adolescents' health needs, including sexual and reproductive health, are met throughout their life cycle. This commitment was reinstated at the ICPD-Plus five few years after. ${ }^{156}$

But opportunities exist for these institutions through their protective and promotional mandates to ensure that adolescents' sexual and reproductive rights are advanced in the region. The appointment of a Special Rapporteur on children, the creation of the unit on children's rights and the use of indicators to assess government's activities are all useful means of realising adolescents' sexual and reproductive rights if properly put into effective use. However, this can only be done in a conducive environment where the independence of NHRIs is ensured, their source of funding guaranteed and the tenure and appointment of their members free from the whims and caprices of the executive.

\footnotetext{
152 Okafor and Agbkwa, loc.cit. (note 25), p. 694.

153 The Third Conference of African National Human Rights Institutions held in Lomé between 12 and 16 March 2001 (known as The Lomé Declaration).

154 Report of the International Conference on Population and Development, UN Doc. A/CONF.171/13, 5-13 September 1994.

155 Fourth World Conference on Women Beijing held on 15 September 1995, UN Doc. A/CONF.177/20, September 1995.

156 UN follow-up meeting of the ICPD held in New York between March and June 1999.
} 